\title{
REALIZATION OF THE RIGHT TO HEALTHCARE OF CONVICTED WITH SERIOUS ILLNESS
}

D0I: 10.36740/WLek202012213

\author{
Oleksandra H. Yanovska' ${ }^{1}$ Oksana P. Kuchynska², Alona V. Chuhaievska ${ }^{3}$ \\ 'SUPREME COURT, KYIV, UKRAINE \\ 2INSTITUTE OF LAW OF TARAS SHEVCHENKO NATIONAL UNIVERSITY OF KYIV, KYIV, UKRAINE \\ 3LAW INSTITUTE OF VADYM HETMAN KYIV NATIONAL UNIVERSITY OF ECONOMICS, KYIV, UKRAINE
}

\begin{abstract}
The aim of the study is to analyze the features of realization mechanism of the rights of convicted persons suffering from a serious illness to release from serving a sentence in order to receive the necessary treatment.

Materials and methods: this study uses a set of methods of scientific knowledge. The empirical basis of the study is the statistics of the State Judicial Administration of Ukraine for 2015-2019 on convicts released from punishment due to their serious illness, statistical materials and case law of Turkey, Georgia, Great Britain, Germany and Greece, generalization of judicial practice of Ukraine, and the personal experience of one of the co-authors of more than 20 years as a lawyer and for 3 years as a judge of the Supreme Court. Conclusions: in order to protect the persons; interests serving sentences and suffering from serious illness, government mechanisms should provide flexibility in the approach to assessing the health of each person, and not just the detection of disease; the authorities assessing the convict's state of health must be independent, and a prisoner must be able to choose physicians not only for treatment but also for assessment of his/her state of health.
\end{abstract}

KEY WORDS: serious illness; exemption from punishment for illness; the right to life and health; protection of the rights of persons in captivity; criminal-legal jurisdictional mechanism of protection

Wiad Lek. 2020;73(12 p. II):2780-2784

\section{INTRODUCTION}

The European context for the humanization of criminal policy provides for the protection of the rights of every person suffering from a serious illness and serving a sentence in a prison. After all, the release of a convict due to illness ensures the realization of the human right to health care and the creation of conditions for effective treatment and recovery. The introduction of the institution of exemption from serving a sentence due to a serious illness in different countries has its own features that allow to study and identify trends, as well as best practices for creating effective mechanisms, both to achieve the goals of criminal justice and to protect the right to life and health care.

\section{THE AIM}

The aim of the study is to analyze the features of the realization mechanism of convicts' rights who have fallen ill with a serious illness, to release from serving a sentence in order to receive the necessary treatment.

\section{MATERIALS AND METHODS}

This study uses a set of methods of scientific knowledge. The empirical basis of the study is the statistics of the State Judicial Administration of Ukraine for 2015-2019 on convicts released from punishment due to serious illness, statistical materials and case law of Turkey, Georgia, Great Britain, Germany and Greece, generalization of Ukrainian case law. This study also used the personal experience of one of the co-authors as a lawyer for more than 20 years and for 3 years as a judge of the Supreme Court.

\section{REVIEW}

In Ukraine, release from punishment for illness was introduced in 2001 with the adoption of the current Criminal Code of Ukraine (hereinafter - the Criminal Code of Ukraine) [1] and is one of the grounds for early release of a person from further imprisonment.

Analysis of statistical data indicates that in Ukraine in $2015,49.5 \%$ of applications for release from punishment due to illness were granted, in 2016 - 49\%, in 2017 - 52\%, in $2018-41 \%$, in $2019-42.2 \%$, i.e. in most cases, the person is not exempt from punishment for illness [2].

In addition, according to the Prosecutor General's Office of Ukraine, 510 prisoners died in penitentiary institutions in 2015, 523 in 2016, 568 in 2017, 484 in 2018, and 517 in 2019 , respectively. And we observe such statistics despite the fact that the number of prisoners is constantly decreasing (for the period 2015 - 2019 - from 70000 to 52.9 thousand, respectively). In addition, as of January 1, 2020, 
1,300 people with disabilities were held in penitentiary institutions in Ukraine [3].

In European countries, statistics on the functioning of exemptions due to illness are rather limited. Thus, in 2017, 9 people were discharged in Georgia; 1 person [4] in Moldova. In the 2018 report, only Lithuania provided information on 5 people released due to serious illness [5].

It should be noted that the high mortality rate in penitentiary institutions of Ukraine is primarily due to inadequate conditions of detention, untimely diagnosis and inadequate medical care provided to convicts, as evidenced by numerous decisions of the European Court of Human Rights (ECHR), which indicate violations Art. 3 of the Convention for the Protection of Human Rights and Fundamental Freedoms (hereinafter - the Convention) (Pokhlebin v. Ukraine, no. 35581/06 [6], Logvinenko v. Ukraine, no. 13448/07 [7], Petukhov v. Ukraine (No. 2), no. $41216 / 13$ [8] and others).

The analysis of our sources allowed us to identify two main approaches to defining the concept of serious diseases, notably: 1) normative definition of the list of serious diseases;2) determination of the serious illness signs a and its impact on the person at the law level.

The authors' own experience of law enforcement activity and analysis of judicial practice in Ukraine shows that in the case of an application for release from punishment due to illness filed by a convict or his/her lawyer, in accordance with the requirements of Part 1 of Art. 539 of the Criminal Procedure Code of Ukraine (hereinafter - CPC of Ukraine) [9] most often the court refuses to grant the petition precisely because of the lack of opinion of the medical advisory commission, which cannot be obtained without the Head Penitentiary's participation. For example, in case № 1-в / 367/1159/2016, the convict applied to the court with a request to resolve the issue of his release from serving a sentence as having suffered a serious illness, but did not attach to it the opinion of a special medical commission. The court granted the prosecutor's request and ordered the Special Medical Commission at the State Penitentiary Service in Kyiv and Kyiv Oblast to conduct a medical examination of the convict and provide the court with a written opinion on the basis for his release from serving a sentence due to serious illness [10].

It has been proved that in Ukraine the assessment of a prisoner's health state is carried out in the health care institutions of penitentiary system, which deprives the convict of the right to choose a physician who will examine $\mathrm{him} / \mathrm{her}$. At the same time, it is argued that the procedure for release from punishment and imprisonment should be based on protecting the rights of prisoners to free access to effective medical care and preventing such treatment as harassment or torture.

\section{DISCUSSION}

Problematic issues of release from serving a sentence due to the fact that the convicted person has a serious illness or reached an old age are permanently the subject of research by both Ukrainian $[11,12]$ and foreign scholars [13-16]. Exemption from serving a sentence due to illness, as scientists note, is one of the manifestations of criminal responsibility humanization. The idea of achieving the objectives of criminal justice through the mitigation of repression and the use of alternatives to imprisonment is directly linked to the task of ensuring the prisoner's right to health care. At the same time, the issue of prisoner's health care is considered both in terms of ensuring free access of prisoners to medical care, and in terms of creating appropriate detention conditions [17].

The Parliamentary Assembly of the Council of Europe (hereinafter - PACE), taking care of the plight of seriously ill prisoners, in Resolution 2082 (2015) recommends the wider introduction of exemption from imprisonment for prisoners suffering from serious illness, it cannot always be provided by penitentiary institutions [18].

ECHR rulings show that the state of penitentiary system in many European countries cannot protect and guarantee the rights of prisoners to adequate medical care. In particular, in the case of Gülay Cetin v. Turkey [19] concerning the non-release of a prisoner with terminal cancer or in the case of Contrada (no. 2) v. Italy [20], in relation to the detention of a person whose state of health was incompatible with detention, a violation of Art. 3 of the Convention regarding the prohibition of inhuman and degrading treatment [21].

In view of the above, the EU Committee of Ministers has developed recommendations requiring States to release persons suffering from serious illnesses as soon as possible, taking into account medical and social criteria [22].

As for the essence or definition of the term "serious illness" of the Criminal Code of Ukraine, unfortunately, it is limited only to the definition of "serious illness of a convict that prevents serving a sentence". Although, in our opinion, it is not the disease itself that is significant, but the consequences it has for the state of health of the convict.

At the same time, Ukraine uses the normatively established List of Diseases as a basis for release from further imprisonment [23], which is mandatory for medical professionals in preparing an appropriate opinion on the prisoner's health.

It should be noted that the definition of serious diseases by approving the official list is not unique in European practice. Thus, in Georgia, the list of serious and incurable diseases, the presence of which is the basis for dismissal, is approved by the Minister of Labor, Health and Social Protection of Georgia, according to Article 39 of the Criminal Code of Georgia [24]. A similar situation is observed in Greece, where a list of serious diseases has also been approved [25].

Another approach is to determine the signs of a serious illness and its impact on the person at the law level, which should be investigated when making appropriate decisions, and medical professionals should only give a reasonable assessment of whether a person's health meets these signs. For example, in Germany there is no such list of diseases, but at the same time there are conditions that must be met by the person's state of health claiming exemption from 
the disease [26]. A similar approach is observed in Poland, Netherlands, France and other countries.

According to Mr. Andreas Gross, this gives grounds for concluding that the assessment of the medical criterion of exemption from serving a sentence due to a serious illness should be based on an individual approach and, in particular, answer the question: does further imprisonment poses threat to the prisoner's health or life, his/her dignity? Whether the treatment and proper conditions can be provided to incarcerated, considering their state of health?

And in general - does the further presence of a person, taking into account the conditions and medical indications, meet the purpose of punishment? [27].

The effectiveness of assessing a prisoner's compliance with medical criteria also depends on the institutional mechanism that ensures that a prisoner has access to the professional care of health professionals who are called upon to draw appropriate conclusions about his/her health. The above-mentioned PACE recommendations and the Guidelines for the Treatment of Prisoners [28] emphasize that prisoners with a serious illness vitally need both unimpeded access to legal aid and access to medical care equivalent to that which they may receive at large. After all, one of the fundamental rights of the patient is the right to choose a doctor and the restriction of this right must be justified by necessity.

In Ukraine medical examination of convicted persons is carried out by the Medical Advisory Commission of health care institutions of State Criminal-Executive Service of Ukraine (hereinafter - SCES). Taking into account the results of the mentioned medical examination, an opinion is immediately drawn up on the convict's medical examination for the presence of a disease determined by the List of Diseases, which is the basis for submitting materials on release of the convict from further serving the sentence to the court.

A similar situation is observed in many other countries. Thus, in Turkey, according to the Law on Execution of Punishments and Security Measures, a medical opinion is drawn up only by the relevant commissions of the Institute of Forensic Medicine, which reports to the Ministry of Justice [29].

Given that limiting the range of facilities and doctors who can conduct the Medical Advisory Commissions creates risks of bias on their part, as well as restricts the rights of the patient prisoner, it seems appropriate to recommend mechanisms for involving independent doctors in the medical examination of prisoners and drawing appropriate conclusions.

Exemption from serving a sentence in Ukraine generally corresponds to European practice and is carried out by the court at the place of serving the sentence on the basis of assessment of both medical (nature, severity of illness) and legal criteria (gravity of the criminal offense, identity of the convict and other circumstances).

However, it should be emphasized that the conclusion of the Medical Advisory Commissions is not binding to the court, because according to Part 2 of Art. 84 of the Criminal
Code of Ukraine in resolving this issue the court considers the crime gravity, the disease nature, the identity of the convict and other circumstances of the case, and therefore, despite the positive conclusion of the commission, the prosecutor's refusal.

Thus, in case № 367/762/14-k the court refused to satisfy the request to the head of the Bucha Correctional Colony № 85 for release from serving the sentence of the convict as having fallen ill with a serious illness. At the hospital, the convict received medical care, but his/her condition deteriorated, a meeting of a special medical commission was held, which, studying the dynamics of the disease, concluded that the diagnosis sentenced the patient to a serious illness, which is the basis for lawsuits materials on the release of convicts from further imprisonment. At the same time, the court argued its refusal as follows: the person was sentenced to 11 years in prison for committing a grave crime; did not admit guilt in the committed crime; served less than half of the sentence; at the court hearing, the doctor did not prove that the convict's illnesses prevented them from serving his/her sentence [30].

Currently, in Ukraine, the court examines such circumstances as behavior during the sentence, compliance with the regime, attitude to work, discipline, degree of correction, evasion of treatment and so on. Other circumstances that may be taken into account by the court include the length of imprisonment, lack of permanent residence and relatives at large, lack of funds, intentional infliction of harm to the convict, which led to illness, and so on.

In fact, the presence of even a fatal illness is not a necessary basis for exempting a person from punishment due to illness. For example, in the case № $11 \mathrm{kp} / 818 / 1429 / 19$ the appellate court granted the prosecutor's complaint and denied the request for exemption from punishment due to illness, although the convict also suffered from a serious illness, namely: HIV infection, the 4-th clinical stage. However, the medical report states that the patient's condition is defined as relatively satisfactory, stable, the course of the patients' disease have a slight positive tendency. In addition, the appellate court additionally took into account the gravity of the crime and the convict's identity, who had been convicted several times before, was released from serving his sentence, but did not take the path of correction, but continued to commit crimes [31].

In general, it should be concluded that the decision to release from punishment due to illness should be provided by an impartial body. In this case, the prisoner in person, his/her representative or their lawyer should be invited to represent their interests and be able to provide evidence, including alternative medical opinions.

\section{CONCLUSIONS}

The rights of prisoners should be limited to the extent that the purpose of punishment is achieved, but States should refrain from violating the inalienable rights of prisoners to life and health. Given the state of the penitentiary system and the systemic problems identified in ECHR decisions, 
special attention should be paid to the prevention of torture and ill-treatment of prisoners, in particular those in need of adequate medical care. States should implement recommendations for statistical monitoring of the release of prisoners, summarize information on the number of requests for release and the results of their consideration, timing of their consideration, the list and nature of diseases that caused them, and so on. In order to protect the interests of persons serving sentences and suffering from a serious illness, and therefore requiring release from serving a sentence, state mechanisms should provide flexibility in the approach to assessing the state of health of each person; authorities assessing the convict's state of health must be independent, and the prisoner must be able to choose doctors not only for treatment but also for the assessment of his/her state of health.

\section{REFERENCES}

1. Kryminalniy kodeks Ukrayiny [Criminal Code of Ukraine]: Zakon Ukrayiny, 05.04.2001, № 2341-III. Available from: zakon.rada.gov.ua/laws/ show/2341-14. [reviewed 2020.08.10] (Ua).

2. Statistichni danni Sudovoyiadministraciyi Ukrainy [CourtAdministration of Ukraine Statistic Data]. Available from: court.gov.ua/inshe/sudova_ statystyka/rik_2019. [reviewed 2020.08.10] (Ua).

3. Kryminalno-vykonavcha systema Ukrayiny v 2019 roci: Statystychnyiy oglyad [Criminal Penal System of Ukraine in 2019: Statistical review]. Tyuremnyy portal, Hromads'ka pravozakhysna orhanizatsiya «Doneczkyiy Memorial». Available from: ukrprison.org.ua/ articles/1581323348. [reviewed 2020.08.10] (Ua).

4. Aebi M. F, Tiago M. M Prisons and Prisoners in Europe 2018: Key Findings of the SPACE I report. Strasbourg: Council of Europe. 2019, 16 p.

5. Aebi M. F, Tiago, M. M Prisons and Prisoners in Europe 2019: Key Findings of the SPACE I report. Strasbourg: Council of Europe. 2020, 27 p.

6. Case of Pokhlebin v. Ukraine (Application no. 35581/06) Judgment of 20.05.2010. Available from: hudoc.echr.coe.int/eng?i=001-98798. [reviewed 2020.08.23]

7. Case of Logvinenko v. Ukraine (Application no. 13448/07) Judgment of 14.10.2010. Available from: hudoc.echr.coe.int/eng?i=001-100972. [reviewed 2020.08.23]

8. Case of Petukhov v. Ukraine (№. 2) (Application no. 41216/1312) Judgment of 12.03.2019. Available from: hudoc.echr.coe.int/ rus?i=001-191703. [reviewed 2020.08.23]

9. Kryminalniy prozecualniy kodeks Ukrayiny [Criminal Procedure Code of Ukraine]: Zakon Ukrayiny, 13.04.2012 № 4651-IV. Available from: zakon.rada.gov.ua/laws/show/4651-17. [reviewed 2020.08.10] (Ua).

10. Uhvala Irpinskogo miskogo sudu Kiyivskoyi oblasti, 25.04.2016, sprava № 367/3066/16-k [Judgement of Irpin City Court, 25.04.2016, case 367/3066/16-k]. Available from: reyestr.court.gov.ua/ Review/58588876. [reviewed 2020.08.10] (Ua).

11. Danchenko K. M Dotrymannya pryntsypu zakonnosti u razi zvil'nennya vid pokarannya za khvoroboyu [Observance of the principle of legality in case of release from punishment for illness]. Pravo i suspil'stvo. 2019;2(2):178-182. (Ua).

12. Dil'na Z.F Shchodo pytannya nadannya zasudzhenym paliatyvnoyi dopomohy: realiyi s'ohodennya [On the issue of providing palliative care to convicts: the realities of today]. Chasopys Natsional'noho universytetu «0stroz'ka akademiya». Seriya «Pravo». 2018;2(18):1-14. Available from: https://j.oa.edu.ua/articles/2018/n2/18dzfdrs.pdf. [reviewed 2020.08.23] (Ua).
13. HandtkeV, Wangmo T, Elger B, BretschneiderW. New Guidance for an Old Problem: Early Release for Seriously III and Elderly Prisoners in Europe. The Prison Journal. 2017;97(2):224-246. doi:10.1177/0032885517692805.

14. Khechumyan A Imprisonment of the Elderly and Death in Custody: The Right to Review. London: Routledge, 2018, 208 p.

15. lacobucci $G$ Early release rules for prisoners at end of life may be «discriminatory», say doctors. BMJ: British Medical Journal (Online). 2019;365. doi:10.1136/bmj.I4140.

16. Handtke V, Bretschneider W, Elger B, Wangmo T.The collision of care and punishment: Ageing prisoners' view on compassionate release. Punishment \& Society. 2017;19(1):5-22.

17. MacDonald M. Overcrowding and its impact on prison conditions and health. International Journal of Prisoner Health. 2018;4(2):65-68. doi: 10.1108/JPH-04-2018-0014.

18. The fate of critically ill detainees in Europe: Council of Europe Parliament Assembly, Resolution 2082, 27.11.2015. Available from: assembly.coe. int/nw/xml/XRef/Xref-XML2HTML-EN.asp?fileid=22284\&lang=en. [reviewed 2020.08.23].

19. Case of Gülay Cetin v. Turkey (Application no.44084/10) Judgment of 05.03.2013. Available from: //hudoc.echr.coe.int/engpress?i=003-4279784-5107667. [reviewed 2020.08.23].

20. Case Contrada (no. 2) v. Italy (Application no. 7509/08) Judgment of 14.04.2015. Available from: hudoc.echr.coe.int/engpress? $\mathrm{i}=003-4665828-5654394$. [reviewed 2020.08.23].

21. Convention for the Protection of Human Rights and Fundamental Freedoms: European Court of Human Rights, Council of Europe, 04.11.1950. Available from: www.echr.coe.int/Documents/ Convention_ENG.pdf. [reviewed 2020.08.23].

22. Recommendation № R (82) 16 on Prison Leave: Council of Europe, Committee of Ministers, 24.09.1982. Available from: prison.eu.org/ IMG/pdf/REC8216E.pdf. [reviewed 2020.08.23].

23. Pro zatverdzhennya Poryadku organizaciyi nadannya medichnoyi dopomogi zasudzhenim do pozbavlennya voli [0n Approval of the Procedure for Healthcare Providing to Custodial Sentenced]: Nakaz Ministerstva Yusticiyi Ukrayiny ta Ministerstva ohorony zdorov'ya Ukrayiny, 15.08.2014 № 348/5/572. Available from: zakon.rada.gov. ua/laws/show/z0990-14\#Text. [reviewed 2020.08.23] (Ua).

24. Imprisonment Code: Law of Georgia, 09.03.2010 № 2696. Available from: matsne.gov.ge/en/document/view/91612?publication=31. [reviewed 2020.08.20].

25. Cheliotis L.K Conditional Release from Prison in Greece: Policy and Practice. Queen Mary School of Law Legal Studies Research. 2009;30:118 doi: ssrn.com/abstract=1476949.

26. German Code of Criminal Procedure: Law of German, 07.04.1987. Available from: https://www.gesetze-im-internet.de/englisch_stpo/ englisch_stpo.html. [reviewed 2020.08.20].

27. The fate of critically ill detainees in Europe: Committee on Legal Affairs and Human Rights, Report, Doc. 13919, 13.11.2015. Available from: www.ecoi.net/en/file/local/1254341/1226_1447746572_document. pdf. [reviewed 2020.08.20].

28. Basic Principles for the Treatment of Prisoners: General Assembly, Resolution 45/111, 14.12.1990. Available from: www.ohchr.org/EN/ Professionallnterest/Pages/BasicPrinciplesTreatment0fPrisoners.aspx. [reviewed 2020.08.20].

29. The Law on the Execution of Penalties and Security Measures: Law of Turkey, 13.12.2004. Available from: www.lawsturkey.com/law/thelaw-on-the-execution-of-penalties-and-security-measures-5275. [reviewed 2020.08.20]. 
30. Uhvala Irpinskogo miskogo sudu Kiyivskoyi oblasti, 11.02.2014, sprava № 367/762/14-k [Judgement of Irpin City Court, 11.02.2014, case 367/762/14-k]. Available from: reyestr.court.gov.ua/Review/37126216. [reviewed 2020.08.23] (Ua).

31. Uhvala Harkivskogo apelyaziynogo sudu, 10.05 .2019 , sprava № 610/3759/18 [Judgement of Kharkivsky Appeal Court, 10.05.2019, case №610/3759/18]. Available from: reyestr.court.gov.ua/ Review/81813301. [reviewed 2020.08.23] (Ua).

The paper was performed at the Department of Criminal Procedure and Criminology of the Institute of Law of Taras Shevchenko National University of Kyiv within the plans of research work in the field of "Doctrine of Law in the Legal System: Theoretical and Practical Aspects".

\section{ORCID and contributionship:}

Oleksandra H. Yanovska: 0000-0001-8451-3775 A, D, F

Oksana P. Kuchynska: 0000-0003-3464-4798 ${ }^{D, E}$

Alona V. Chuhaievska: 0000-0002-5522-2693 B, C,D

\section{Conflict of interest:}

The Authors declare no conflict of interest.

\section{CORRESPONDING AUTHOR}

\section{Oleksandra H. Yanovska}

Supreme Court

01043, Ukraine, Kyiv, P. Orlyka st., 4-a

tel: +380674415434

e-mail: yanovskaya.a@ukr.net

Received: 03.09.2020

Accepted: 30.11 .2020

A - Work concept and design, B - Data collection and analysis, C - Responsibility for statistical analysis, D-Writing the article, $\mathbf{E}$-Critical review, $\mathbf{F}$ - Final approval of the article 